\section{THE LATE HENRI EY}

Dear Sir,

Those of us who had the privilege of knowing Henri Ey at Bonneval will remember with nostalgia the beautiful Abbey of Saint-Florentin on the banks of the Loire. There in his study, the old monks' kitchen, he would hold his weekly case conference, so often returning to his favourite subject, the nature of delusion - that paradox of reason. Madame Ey always kept a warm welcome for visitors from all over the world, and tea on the lawn was an event. I remember the 'Master' settled in his deckchair, his cat on his lap and with a malicious twinkle in his eye proclaim himself psychiatry's first militant and decry the limitations of the isolationist approaches of medicine, anti-psychiatry and psychoanalysis in turn ('I would not even have my cat analysed, especially my cat'-for he was very fond of his cat).

Following his monumental Traite des Hallucinations in 1973, the culmination of a lifetime of scientific work of international proportion, he went on to publish with others, his Psychophysiologie du Sommeil et Psychiatrie (Masson, Paris, 1975) because he believed the acute insanities were to be understood in terms of arrested sleep states and also revised his original organo-dynamic model based on Hughlings Jackson's ideas (Privat, Toulouse, 1975). He then turned his thoughts to the problem of the internment of dissidents and the abuse of psychiatry with Defense et Illustration de la Psychiatrie (Masson, Paris, 1977) and left uncompleted his Criminologie et Psychiatrie and Nier ou Gutrir les Maladies Mentales.
He retired in 1970 to his childhood village of Banyuls-dels-Apres and the vineyards of his beloved Catalonia to pursue his writings and to give more time to his passionate interest, bull-fighting.

His death is a sad loss.

Prim Evans

Watford General Hospital,

Shrodells Wing.

Vicarage Road,

Watford, Herts WDI $8 H B$

\section{MEDICAL HYPNOSIS}

Dear Sir,

We have been requested to write a fourth edition of our Handbook of Medical Hypnosis, which was first published in 1956.

We feel that the most valuable and useful way of collecting material for an up-to-date book on this subject is to ask if any members interested in psychotherapy and using hypnosis as an adjuvant to their therapy (particularly if engaged in active research) would contact us.

A Section of Hypnotherapy now exists at the Royal Society of Medicine.

I 5 a Harley Street,

Gordon Ambrose

London $W_{I}$

Golden Hill,

Windmill Lane,

Llantwit Major, Glam.

George Newbold

\title{
ANNOUNGEMENTS
}

\section{World Psychiatric Association}

The World Psychiatric Association General Assembly at its meeting in Honolulu in August 1977 adopted a resolution establishing a Committee to review the abuse of psychiatry for political reasons. In January 1978 the Executive Committee of WPA, at a meeting in New Delhi, decided to set up a legal sub-committee whose first task would be to propose procedure for the Committee.

Professor Pierre Pichot, President of the WPA, has now invited Mr Anthony McNulty to compose this sub-committee and to act as its chairman. $\mathrm{Mr}$ McNulty, who is Director of the British Institute of Human Rights, and former Secretary to the European Commission of Human Rights, has accepted this invitation and has asked two present members of the
European Commission (Dr Karl-Aag Norgaard (Denmark) and Mr Brendan Kiernan (Republic of Ireland) to join him. Mr McNulty states that he hopes that this three-man sub-committee can submit proposals to the Executive Committee before the end of the summer.

\section{Denis Leigh Secretary-General, World Psychiatric Association}

\section{Disclaimer}

The views expressed in articles published in the Bulletin (except official College material) are entirely the authors' own and do not represent College policy. 